BMJ Paediatrics Open

\title{
Gabapentin for the treatment of pain manifestations in children with severe neurological impairment: a single-centre retrospective review
}

\author{
Aedin Collins, ${ }^{01}$ Rory Mannion, ${ }^{1}$ Annemarie Broderick, ${ }^{1,2}$ Séamus Hussey, ${ }^{1,2,3}$ \\ Mary Devins, ${ }^{4}$ Billy Bourke ${ }^{1,2}$
}

\begin{abstract}
To cite: Collins A, Mannion R, Broderick $A$, et al. Gabapentin for the treatment of pain manifestations in children with severe neurological impairment: a single-centre retrospective review. BMJ Paediatrics Open 2019;3:e000467. doi:10.1136/ bmjpo-2019-000467
\end{abstract}

Received 20 February 2019 Accepted 18 June 2019

\section{ABSTRACT}

Pain, irritability and feeding intolerance are common symptoms affecting quality of life in children with severe neurological impairment (SNI). We performed a retrospective study to explore the use of gabapentinoid medications for symptom control in children with SNI. Patients attending the palliative care or gastroenterology department being treated with gabapentin for irritability, vomiting or pain of unknown origin were included. Information was gathered retrospectively from medical documentation. Irritability was reduced in 30 of the 42 patients included. Gabapentin was discontinued in 15 children, 12 of whom then received pregabalin. Three children had a good response to pregabalin, six a minimal improvement and three no improvement. These results support the use of gabapentinoids in this patient cohort.

\section{INTRODUCTION}

Pain and distress symptoms are among the most challenging clinical problems faced by those caring for children with severe neurological impairment (SNI). Up to $50 \%$ of children with severe cognitive impairment are reported to have pain episodes every week. ${ }^{1}$ Even in the context of an apparent gastrointestinal source, the underlying cause for pain and irritability often remains unclear. ${ }^{2}$ Both central neuropathic pain and visceral hyperalgesia, an increased response and sensitivity to stimuli within the gastrointestinal tract, ${ }^{3}$ are potential causes of this pain and irritability. ${ }^{45}$

In a study published over a decade ago, Hauer et al first identified the potential benefits of gabapentin in nine children with $\mathrm{SNI}^{4}$ and a follow-up study by the same author identified an improvement in pain behaviours in over $90 \%$ of 22 children treated with gabapentin. ${ }^{5}$ We performed a retrospective study in 42 patients, to see if the findings of Hauer's seminal studies ${ }^{45}$ could be replicated, and to investigate if pregabalin is an appropriate second-line agent for this indication.

\section{METHODS}

A retrospective chart review of paediatric patients with SNI attending the gastroenterology and palliative care services at Our Lady's Children's Hospital, Crumlin was performed. All patients who had been prescribed gabapentin treatment for pain or irritability of unknown origin were included. Information was gathered from medical notes. Prior to commencing gabapentin all children in this study were formally clinically evaluated by the paediatric gastroenterology or palliative care services, and investigated or treated empirically for organic disease, without improvement of their symptoms. The rationale for using gabapentin or pregabalin in these children with possible visceral hyperalgesia was based on its role in reducing neuropathic pain as well as its central effects. ${ }^{6}$

Patients were not involved in the design or the conduction of this research.

\section{RESULTS}

There were 42 patients included in the study, with follow-up ranging from 3 to 63 months and a mean duration of 21 months-a total of 75 patient-years' follow-up. The most frequently reported symptoms prior to commencement of gabapentin were crying and irritability, occurring in 39 and 37 children, respectively. A good or very good overall response to gabapentin was reported in 25 patients, while minimal or no response occurred in eight and seven patients, respectively. Improvement in irritability was reported in 30 patients, and 17 patients required less pain medication (table 1). Increased lethargy was reported in three cases and there were isolated cases of vomiting, alopecia, twitching and raised liver enzyme levels. There was an apparent loss of response over time in four children (table 1 ). The mean duration of gabapentin treatment 


\begin{tabular}{|lrc|}
\hline Table 1 Effectiveness of gabapentin & & \\
\hline \multicolumn{1}{|c|}{$\mathbf{n}$} & $\%$ \\
\hline Overall response to gabapentin & & \\
\hline Deteriorated & 1 & 2 \\
\hline None & 8 & 19 \\
\hline Minimal & 7 & 17 \\
\hline Good & 10 & 24 \\
\hline Very good & 15 & 36 \\
\hline Not documented & 1 & 2 \\
\hline Change in irritability & & \\
\hline Yes & 30 & 71 \\
\hline No & 11 & 26 \\
\hline Not documented & 1 & 2 \\
\hline Pain reduction & & \\
\hline Yes & 17 & 40 \\
\hline No & 23 & 55 \\
\hline Not documented & 2 & 5 \\
\hline Adverse effects & & \\
\hline None & 31 & 74 \\
\hline Improvement reducing over time & 4 & 10 \\
\hline Lethargy & 3 & 7 \\
\hline Twitching & 1 & 2 \\
\hline Alopecia & 1 & 2 \\
\hline Vomiting & 1 & 2 \\
\hline Elevated liver enzymes & 1 & 2 \\
\hline Gabapentin discontinued & 15 & 36 \\
\hline Alopecia & & \\
\hline Asymptomatic & 1 & 7 \\
\hline No improvement & 7 \\
\hline Changed to pregabalin & 70 \\
\hline
\end{tabular}

in those four children was 25 months. All were on the highest dose of $60 \mathrm{mg} / \mathrm{kg} /$ day.

Gabapentin was switched to pregabalin as a second-line agent in 12 of the 42 children. The dose of gabapentin was maximised prior to switching in 11 of the children. There was no noted effect of pregabalin in two patients, minimal in six, good in three and not documented in one (table 2). The mean duration of follow-up of patients on pregabalin was 13.5 months.

\section{DISCUSSION}

Acknowledging the limitations surrounding the retrospective nature of this study, it nevertheless serves to corroborate the observations of Hauer $e t a t^{5}$ and more than doubles the numbers of reported children with SNI receiving gabapentin. It suggests a possible role for pregabalin where gabapentin fails or is not tolerated. Perhaps more importantly, it provides evidence for the

\begin{tabular}{|c|c|c|}
\hline & $\mathbf{n}$ & $\%$ \\
\hline Total switch to pregabalin & 12 & \\
\hline \multicolumn{3}{|l|}{ Rationale for change to pregabalin } \\
\hline Lethargy & 2 & 17 \\
\hline Ongoing symptoms & 6 & 50 \\
\hline Elevated liver enzymes & 1 & 8 \\
\hline Improvement reducing over time & 3 & 25 \\
\hline \multicolumn{3}{|l|}{ Efficacy of pregabalin } \\
\hline Deteriorated & 0 & 0 \\
\hline None & 2 & 17 \\
\hline Minimal & 6 & 50 \\
\hline Good & 3 & 25 \\
\hline Very good & 0 & 0 \\
\hline Not documented & 1 & 8 \\
\hline
\end{tabular}

efficacy of these medications in a very challenging and growing cohort of children where there otherwise exist extremely limited therapeutic options.

Contributors AC conceptualised and designed the study, designed the data collection instruments, collected the data, drafted the initial manuscript, and reviewed and revised the manuscript. RM designed the study, designed the data collection instruments, collected the data, and reviewed and revised the manuscript. SH and $\mathrm{AB}$ conceptualised the study, designed the data collection instruments and critically reviewed the manuscript for important intellectual content. BB and MD conceptualised and designed the study, designed the data collection instruments, carried out the initial analysis, and reviewed and revised the manuscript. All authors approved the final manuscript as submitted and agree to be accountable for all aspects of the work.

Funding The authors have not declared a specific grant for this research from any funding agency in the public, commercial or not-for-profit sectors.

Competing interests None declared.

Patient consent for publication Not required.

Ethics approval Ethical approval was granted by the Research Ethics Committee of Our Lady's Children's Hospital, Crumlin.

Provenance and peer review Not commissioned; externally peer reviewed.

Open access This is an open access article distributed in accordance with the Creative Commons Attribution Non Commercial (CC BY-NC 4.0) license, which permits others to distribute, remix, adapt, build upon this work non-commercially, and license their derivative works on different terms, provided the original work is properly cited, appropriate credit is given, any changes made indicated, and the use is non-commercial. See: http://creativecommons.org/licenses/by-nc/4.0/.

\section{REFERENCES}

1. Breau LM, Camfield CS, McGrath PJ, et al. The incidence of pain in children with severe cognitive impairments. Arch Pediatr Adolesc Med 2003;157:1219-26.

2. Siden HB, Carleton BC, Oberlander TF. Physician variability in treating pain and irritability of unknown origin in children with severe neurological impairment. Pain Res Manag 2013;18:243-8.

3. Mayer EA, Gebhart GF. Basic and clinical aspects of visceral hyperalgesia. Gastroenterology 1994;107:271-93.

4. Hauer JM, Wical BS, Charnas L. Gabapentin successfully manages chronic unexplained irritability in children with severe neurologic impairment. Pediatrics 2007;119:e519-22.

5. Hauer JM, Solodiuk JC. Gabapentin for management of recurrent pain in 22 nonverbal children with severe neurological impairment: a retrospective analysis. J Palliat Med 2015;18:453-6.

6. Serpell MG, Neuropathic pain study group. Gabapentin in neuropathic pain syndromes: a randomised, double-blind, placebo-controlled trial. Pain 2002;99:557-66. 